\title{
ANALISIS PERAN PELATIHAN DALAM MENINGKATKAN PRESTASI KERJA KARYAWAN PADA PERUSAHAAN BATA RINGAN JAYABRIX LAMONGAN
}

\author{
${ }^{1}$ Ahmad Yani Syaikhudin \\ Fakultas Ekonomi, Universitas Islam Darul 'ulum \\ Email ahyani.unisda@gmail.com \\ ${ }^{2}$ Ahmad Fathur Rozi \\ Fakultas Ekonomi, Universitas Islam Darul 'ulum \\ Email fathurrozi@unisda.ac.id
}

\begin{abstract}
Today the industry is growing and developing rapidly in various places. The purpose of establishing these industries is inseparable from the objectives to be achieved by the company. These objectives include to obtain large profits with minimal production costs. The "Jayabrix Indonesia" Lightweight BrickCompany in Paciran Lamongan is one of the national private companies engaged in the production of several Lightweight Brick. For this company to achieve the above goals and maintain consumer confidence is not an easy thing. The existence of very tight market competition will force the company to be able to implement a good strategy in an effort to achieve the above goals. From observations, interviews, and joint observations with employees of the Lightweight Brick company "Jayabix" in Lamongan, the authors found a problem where the main cause of low employee performance is because they are less capable and less able and less skilled at work so the way they work is less effective and not efficient which ultimately affects the productivity of the company. This is what the writer will try to improve employee work performance so that the productivity of the company goes well, one of them is by using research methods. After carrying out data analysis, it can be seen that the correlation coefficient $(r)$ is 0.708 and the determination coefficient is 50,3\%, meaning that training has an important role in employee performance, then after the hypothesis testing is known, $t$ count itung $t_{\text {table }}$ is $9,214>2,358$. shows a strong role between training and employee performance.
\end{abstract}

Keyword : training, work performance, company

\begin{abstract}
ABSTRAK
Saat ini industri ini berkembang dan berkembang pesat di berbagai tempat. Tujuan pendirian industri ini tidak terlepas dari tujuan yang ingin dicapai oleh perusahaan. Tujuan ini termasuk untuk memperoleh keuntungan besar dengan biaya produksi minimal. Bata Ringan "Jayabrix Indonesia" Perusahaan di Paciran Lamongan adalah salah satu perusahaan swasta nasional yang bergerak dalam produksi beberapa Bata Ringan. Bagi perusahaan ini untuk mencapai tujuan di atas dan mempertahankan kepercayaan konsumen bukanlah hal yang mudah. Adanya persaingan pasar yang sangat ketat akan memaksa perusahaan untuk dapat menerapkan


strategi yang baik dalam upaya mencapai tujuan di atas. Dari pengamatan, wawancara, dan pengamatan bersama dengan karyawan perusahaan Bata Ringan "Jayabix" di Lamongan, penulis menemukan masalah di mana penyebab utama rendahnya kinerja karyawan adalah karena mereka kurang mampu dan kurang mampu serta kurang terampil dalam pekerjaan sehingga cara kerjanya kurang efektif dan tidak efisien yang pada akhirnya mempengaruhi produktivitas perusahaan. Inilah yang akan penulis coba untuk meningkatkan kinerja kerja karyawan sehingga produktivitas perusahaan berjalan dengan baik, salah satunya adalah dengan menggunakan metode penelitian. Setelah melakukan analisis data, dapat diketahui bahwa koefisien korelasi (r) adalah 0,708 dan koefisien determinasi adalah 50,3\%, artinya pelatihan memiliki peran penting dalam kinerja karyawan, maka setelah pengujian hipotesis diketahui, $\mathrm{t}$ hitung tabelnya adalah 9.214> 2.358. menunjukkan peran yang kuat antara pelatihan dan kinerja karyawan.

Kata kunci : Pelatihan, Prestasi Kerja dan Perusahaan

\section{PENDAHULUAN}

Unsur manusia dalam suatu perusahaan ataupun dalam aktivitas yang lain mempunyai peranan yang sangat penting. Karena praktek manajemen dalam fungsi fungsinya baik secara langsung maupun tidak langsung tidak lepas dari unsur manusia. Setiap industri atau perusahaan yang didirikan pasti mempunyai tujuan tertentu, tujuan tersebut diantaranya adalah untuk memaksimalkan laba dan meraih prospek masa depan yang cerah. Untuk mencapai tujuan tersebut disamping diperlukan suatu pengelolaan yang serius juga dibutuhkan tenaga kerja manusia sebagai jalan kelancaran perusahaan.

Berdasarkan pengamatan yang penulis lakuakan pada perusahaan Bata Ringan "Jayabix" Lamongan ini. Dimana sebab utama rendahnya prestasi kerja karyawan adalah karena mereka banyak kurang mampu serta kurang terampil dalam bekerja sehingga cara kerja kurang efektif dan tidak efisien yang pada akhirnya mempengaruhi prokduktivitas perusahaan.

Pada saat ini belum ada suatu perusahaan yang dapat melaksanakan tugas-tugasnya tanpa memerlukan manusia sebagai tenaga kerja. Dengan menyadari pentingnya tenaga kerja, maka perusahaan mengadakan upaya untuk pengembangan-pengembangan tenaga kerja dalam rangka meningkatkan dan memperbaiki pengetuhan dan keterampilan karyawan agar dapat menghasilkan output yang berkualitas tinggi.

Dalam Pengembangan tenaga kerja Menurut Hasibuan (2016:69), adalah suatu usaha meningkatkan kemampuan teknis, teoritas, konseptual dan moral karyawan sesuai dengan kebutuhan pekerjaan/jabatan melalui pendidikan dan latihan. 
Pengembangan tenaga kerja ini harus dilakukan oleh pimpinan perusahaan antara lain dengan mengadakan kegiatan pelatihan. Dari kegiatan pelatihan dapat memberikan bekal dan informasi-informasi tentang kegiatan perusahaan secara umum maupun secara khusus kepada karyawan. Pelatihan juga untuk untuk meningkatkan penguasaan teori dan keterampilan dalam memutusakan terhadap persoalan-persoalan yang menyangkut kegiatan mencapai tujuan.

Menurut Rachmawati (2008:110), pelatihan merupakan wadah lingkungan bagi karyawan, di mana mereka memperoleh atau mempelajari sikap, kemampuan, keahlian, pengetahuan, dan perilaku spesifik yang berkaitan dengan pekerjaan. Perusahaan dapat menyampaikan apa dan bagaimana tugas-tugas yang akan dilaksanakan oleh tenaga kerja sehingga yang bersangkutan benar-benar telah meiliki kesiapan dalam melaksanakan tugasnya.

\section{LANDASAN TEORI}

Pengertian pelatihan di sini adalah proses pembelajaran atau pengasahan skill yang memungkinkan pegawai melaksanakan pekerjaan yang sekarang sesuai dengan standar yang telah di tetapkan oleh perusahaan.

Menurut Widodo (2015:82), pelatihan merupakan serangkaian aktivitas individu dalam meningkatkan keahlian serta pengetahuan secara sistematis sehingga mampu memiliki kinerja yang profesional di bidangnya.

Menurut Rivai (2011:212), pelatihan adalah proses secara sistematis mengubah tingkah laku pegawai untuk mencapai tujuan organisasi. Pelatihan berkaitan dengan keahlian dan kemampuan pegawai untuk melaksanakan pekerjaan saat ini.

Dari beberapa pendapat ahli diatas, pelatihan adalah diman sebuah proses untuk meningkatkan kompetensi karyawan dan dapat melatih skill, kemampuan, keterampilan, keahlian dan pengetahuan karyawan guna melaksanakan pekerjaan secara efektifivitas dan efisien untuk mencapai tujuan di suatu perusahaan.

Tujuan pelatihan yang dilakukan oleh perusahaan adalah untuk meningkatkan produktivitas, meningkatkan kualitas, meningkatkan perkembangan kemampuan dan keahlian personel guna mendukung perencanaan Sumber Daya Manusia 
Menurut Carrel dalam Salinding (2011:15) mengemukakan delapan tujuan utama program pelatihan antara lain:

a. Memperbaiki kinerja

b. Meningkatkan skill serta keterampilan karyawan

c. Memecahkan permasalahan

Pelatihan bertujuan untuk meningkatkan penguasaan teori dan keterampilan memutusakan terhadap persoalan-persoalan yang menyangkut kegiatan untuk mencapai tujuan.

Masalah personalia dalam perusahaan bukan merupakan tanggung jawab manajemen saja, melainkan banyak pihak yang turut bertanggung jawab. Sungguh demikian, namun yang bertanggung jawab mengenai fungsi personalia dalam badanbadan usaha adalah setiap manajer dalam badan usaha yang bersangkutan.

Seiring dengan majunya zaman, banyak pemimpin perusahaan menyadari bahwa berhasil atau tidaknya usaha memperbaiki produksi banyak tergantung kepada unsur manusianya yang melakukan pekerjaan. Setiap pimpinan dalam perusahaan bertanggung jawab untuk memajukan atau memperkembangkan kecakapan karyawan.

Dengan memberikan pelatihan karyawan dimaksudkan keahlian kerja karyawan sehingga didalam melaksanakan tugas-tugas dapat lebih baik.Pelatihan merupakan suatu kegiatan yang dapat membantu karyawan dalam menambah kemampuan dan menimbulkan perubahan dalam kebiasaan bekerja serta kegiatan-kegiatan itu berhubungan dengan pekerjaan tertentu.Kerja atau kinerja merupakan pengorbanan jasmani dan pikiran yang dapat menghasilkan barang atau jasa dengan memperoleh imbalan prestasi

Pengertian Kinerja Menurut Simanjuntak (2015:131), kinerja adalah tingkatan pencapaian hasil atas pelaksanaan tugas tertentu. Simanjuntak juga mengartikan kinerja individu sebagai tingkat pencapaian hasil kerja seseorang dari sasaran yang harus dicapai atau tugas yang harusdilaksanakan dalam kurun waktu tertentu.

Sedangkan Menurut Mangkunegara (2009:9), kinerja karyawan (prestasi kerja) adalah hasil kerja secara kualitas dan kuantitas yang dicapai oleh seseorang karyawan dalam melaksanakan tugasnya sesuai dengan tanggung jawab yang diberikan kepadanya. 
Dari beberapa pendapat diatasadalah situasi hasil kerja yang diperoleh seseorang dalam melaksanakan tugas-tugas yang dibebankan kepadanya yang didasarkan atas kecakapan, kesungguhan dan pengalaman serta waktu. Banyak pendapat yang memiliki pengertian yang sama.Presentasi adalah apa yang dihasilkan dalam arti bahwa banyak produksi yang dihasilkan oleh seseorang (karyawan), serta beberapa tugas yang dapat diselesaikan, yang dapat dibebankan kepada seseorang (karyawan).

Hubungan pelatihan terhadap presentasi kerja adalah adanya hubungan yang erat antara latihan yang dapat dilihat dengan kenaikan kualitas maupun kuantitas serta satuan waktu yang dipergunakan untuk menyelesaikan suatu pekerjaan yang dibebankan kepada karyawa suatu keragu-raguan tentang suatu tugas atau pekerjaan arti tugas dengan cepat dan tepat. Dengan demikian, kerja membuat keryawan dengan semangat dan penuh keyakinan.Adapun Indikatornya adalah ukuran kuantitatif dan kualitatif yang mengambarkan dengan tingkat pencapaian suatu sasaran atau tujuan yang telah ditetapkan.

Indikator kinerja merupakan sesuatu yang dihitung dan diukur serta digunakan sebagai dasar yang digunakan sebagai dasar untuk menilai atau melihat tingkat kinerja Sedamayanti (2010:198),indikator kinerja digunakan untuk meyakinkan bahwa kinerja demi hari organisasi/ unit kerja yang bersangkutan menunjukkan kemampuan dalam rangka dan atau menuju tujuan dan sasaran yang telah ditetapkan.

Indikator untuk mengukur kinerja karyawan secara individu ada enam (Bernadin dalam Nursasongko, 2012:22), yaitu:
a. Kualitas
b. Kuantitas
c. Ketepatan waktu
d. Efektivitas
e. Kemandirian
f. Komitmen kerja 


\section{METODE PENELITIAN}

\section{Jenis Penelitian}

Melalui survey, pendahuluan yang dilakukan untuk mengetahui masalah yang terjadi berkenaan dengan penelitian.

\section{Lokasi Penelitian}

Adapun objek penelitian yang penulis ambil pada Perusahaan Bata Ringan "Jayabix" Lamongan yang terletak di Desa Kemantren, kecamatan Paciran, Kabupaten Lamongan

\section{Teknik Sampling}

Teknik sampling merupakan teknik pengambilan sampel (Sugiono, 2015:116), penelitian initidak menggunakan populasi yang banyak, melainkan hanya diambil sampel, yang dianggap representatif, teknik yang digunakan dalam penelitian ini adalah teknik random sampling.

\section{Sumber Data}

1. Data primer

Data yang diperoleh langsung dari perusahaan Bata Ringan "Jayabix" Lamongan dengan cara wawancara langsung dengan pihak manajer pesonalia.

2. Data sekunder

Data yang diperoleh dari dokumen tertulis, buku dan literatur yang berhubungan dengan obyek penelitian.

\section{Analisis Data}

1. Teknik Pengujian Hipotesa (r)

Digunakan untuk mencari ada tidaknya hubungan antara variabel Pelatihan (x) dengan variable prestasi kerja (y).

2. Koefiien derteminant $\left(\mathrm{r}^{2}\right)$

Untuk mengetahui besarnya kontribusi variabel bebas signifikan terhadap variabel terikat (y) atau sebaliknya.

3. Uji t (Uji Signifikansi)

Pengujian hipotesis menggunakan uji $\mathrm{t}$ dengan maksud untuk mengetahui apakah variabel bebas $(\mathrm{x})$ secara individu mempunyai hubungan yang signifikan terhadap variabel terikat $(\mathrm{y})$ 


\section{PEMBAHASAN}

Dalam penelitian ini penulis mencoba untuk memberikan gambaran pencapaian hasil atas pelaksanaan tugas kinerja karyawan. Sebelum penulis menguraikan teknik penilaian presentasi kerja serta pelatihannya,mengenai gambaran proses produksi yang dihasilkan oleh perusahaan PT. Jayabrix Indonesia. Proses produksi bersifat continyu (terus menerus) melalui beberapa tingkat proses dari bahan menta sampai menjadi bahan jadi, dimana prosedur dari masing-masing tingkat tidak dapat di loncati sampai menjadi barang jadi. Proses produksiseperti ini digunakan perusahaan untuk memproduksi secara masal.Bahan baku yang digunakan dalam proses produksi pada perusahaan seperti:Semen, pasir, kapur, air dan bahan penunjang lainya

Dalam penerapan pelatihan adalah proses secara sistematis mengubah tingkah laku pegawai untuk mencapai tujuan organisasi. Pelatihan berkaitan dengan keahlian dan kemampuan pegawai untuk melaksanakan pekerjaan saat ini.

Pelatihan bertujuan untuk meningkatkan penguasaan teori dan keterampilan, penilaian diharapkan karyawan diperusahaan dapat lebih meningkatkan atau dapat memperbaiki cara kerja mereka, sehingga mereka bekerja dapat dengan lebih efisien dan karyawan mampu melaksanakan kerja dengan baik.

Penggunaan bentuk metode pelatihan harus tepat,karena kurang tepatnya metode pelatihan prestasi kerja karyawan tetap rendah meskipun ada pelatihan.

Adapun skor penilaian yang ditetapkan untuk menguraikan dalam indikator prestasi kerja karyawan perusahaan Bata Ringan Jayabixadalah seperti yang tercantumpada label 1 sebagai berikut: 
Tabel 1

Skor Penilaian Pelatihan

Pada Perusahaan Bata Ringan "Jayabix” Lamongan

\begin{tabular}{|l|c|}
\hline \multicolumn{1}{|c|}{ Keterangan } & Nilai \\
\hline Sangat Baik & $80-90$ \\
Baik & $60-79$ \\
Cukup & $40-59$ \\
Kurang & $20-39$ \\
Sangat Kurang & $0-19$ \\
\hline
\end{tabular}

Data yang diperoleh dari penelitian ini perlu dianalisa lebih lanjut sehingga dapat diketahui hasilnya guna memecahkan permsalahan yang ada.Sedangkan analisa data ini dilakukan dengan menggunakan teknik statistic

Di ketahui nilai korelasi antara pelatihan dengan prestasi kerja karyawan Bata Ringan "Jayabix" sebesar 70,8\% nilai Korelasi menunjukan hasil Positif, yang berarti hubungan yang terjadi antara dua variabel searah dimana semakin banyak pelatihan, maka semakin banyak prestasi kerja yang akan di capai

Dari Hasil pengelolaan Menggunakan Statistical Package for the Social Sciences (SPSS) di dapat kan Hasil nilai t-hitung sebesar 9,214 dengan apha sebesar 10\% dan derajat kebebasan $(\mathrm{dk})=\mathrm{n}-2$ yaitu 120-2 = 118, maka berdasarkan tabel distribusi $\mathrm{t}$ dua pihak, di dapatkan hasil t-tabel 2.358. Dalam pengujian hipotesa di dapatkan bahwa Nilai t hitung > t tabel yaitu 9,214 > 2.358. Hal yang menunjukkan bahwa hipotesa nol (Ho) ditolak dan Ha diterima.

Berarti adanya peranan yang kuat antara pelatihan dengan prestasi kerja atau dapat dikatakan bahwa apabila pelatihan yang diberikan terhadap karyawan dilaksanakan secara tepat dan kebutuhan serta kondisi karyawan, maka prestasi kerja karyawan dapat meningkat sesuai dengan yang diharapkan perusahaan. Dengan ini hipotesa yang penulis ajukan atau kemukakan telah terbukti kebenarannya. 
Tabel 2. Koefisien Determinasi

\begin{tabular}{|c|l|l|l|l|}
\hline \multicolumn{5}{|c|}{ Model Summary } \\
\hline Model & $\mathrm{R}$ & $\begin{array}{l}\mathrm{R} \\
\text { Square }\end{array}$ & $\begin{array}{l}\text { Adjusted } \\
\mathrm{R} \\
\text { Square }\end{array}$ & $\begin{array}{l}\text { Std. } \\
\text { Error of } \\
\text { the } \\
\text { Estimate }\end{array}$ \\
\hline 1 & $.708^{\mathrm{a}}$ & .503 & .497 & 2.81269 \\
\hline
\end{tabular}

Berdasarkan pengelolaan Data Koefesiensi Kolerasi Dengan hasil perhitungan sebesar $\mathrm{R}=$ 0.708. Angka pada $\mathrm{R}$ dalam tabel koefisien diterminasi adalah angka yang menunjukan kuatnya hubungan antara variabel Pelatihan $(\mathrm{X})$ dan Variabel prestasi kerja Karyawan (Y).

Menurut Sugiono (2015:231) Kuatnya pengaruh variabel bebas terhadap Variabel terikat berada pada tingkat kuat.

Sedangkan Berdasarkan pengelolaan Data Koefesiensi Kolerasi Dengan hasil perhitungan adalah $=0.708$, maka dapat di katagorikan bahwa pengaruh yang di berikan variabel Pelatihan dalam meningkatkan prestasi kerja karyawan adalah mempunyai pengaruh yang kuat. Selain itu, di peroleh koefisien determinasi $\mathrm{R}^{2}=0.503$ $=50,3 \%$. $\mathrm{R}$ adalah angka yang menunjukan besarnya pengaruh variabel Pelatihan $(\mathrm{X})$ dengan Variabel prestasi kerja Karyawan (Y). Secara diskriptif, pengaruh variabel X terhadap Variabel Y sebesar 50,3\% dan sisanya $49.7 \%$ di pengaruhi oleh faktor-faktor lain di luar pelatihan.

\section{SIMPULAN DAN SARAN}

\section{Simpulan}

Berdasarkan dari hasil pembahasan yang telah di kemukakan oleh penulis adanya peranan yang kuat antara pelatihan dengan prestasi kerja atau dapat dikatakan bahwa apabila pelatihan yang diberikan terhadap karyawan dilaksanakan secara tepat dan kebutuhan serta kondisi karyawan, maka prestasi kerja karyawan dapat meningkat sesuai dengan yang diharapkan perusahaan. Dengan ini hipotesa yang penulis ajukan atau kemukakan telah terbukti kebenarannya. 
Setelah penulis menganalisa data dengan menggunakan koefisien korelasi Pelatihan dalam meningkatkan prestasi kerja karyawan adalah mempunyai pengaruh yang kuat. Selain itu, di peroleh koefisien determinasi $\mathrm{R} 2=0.503=50,3 \%$. $\mathrm{R}$ adalah angka yang menunjukan besarnya pengaruh variabel Pelatihan (X) dengan Variabel prestasi kerja Karyawan (Y). Secara diskriptif, pengaruh variabel $\mathrm{X}$ terhadap Variabel $\mathrm{Y}$ sebesar 50,3\% dan sisanya $49.7 \%$ di pengaruhi oleh faktor-faktor lain di luar pelatihan.

\section{Saran}

Agar karyawan merasa diperhatika hendaknya perusahaan selalu memonitor prestasi kerja karyawan dengan cara tetap memberikan penilaian terhadap prestasi kerja mereka. Bila prestasi kerja karyawan belum sesuai dengan satu cara untuk mengatasi hal tersebut adalah dengan memberikan latihan yang efektif berarti bahwa metode latihan yang diberikan harus sesuai dengan kondisi karyawan. Dengan cara tersebut karyawan akan dapat meningkatkan prestasinya sesuia dengan yang ditetapkan oleh perusahaan.

\section{DAFTAR PUSTAKA}

Alex S Nitisemito,Management Pesonslia, Cetakan II penerbit Sasmito Bros, Jakarta, 2008

M. manulang, Management Personalia, Cetakan Keempat, Penerbit Asara Baru, Jakarta, 2010

Poerwadaminto wjs, Kamus Bahasa Indonesia, Penerbit Balai Pustaka, Jakarta 1974

T. Hani Handoko Management Personalia dan Sumber Daya Manusia, Penerbit Liberty, Yogyakarta,

Sadili Samsudin, 2010. Manajemen Sumber Daya Manusia. Edisi ke 3 penerbit CV PUSTAKA SETIA, Bandung.

Malayu Hasibuan,edisi revisi,tahun 2017. Manajemen Sumberdaya Manusia Penerbit Bumi Aksara

T. Hani Handoko, 2012. Manajemen Personalia \& Sumberdaya Manusia. Edisi ke dua penerbit BPFE-YOGYAKARTA.

Malayu S.P. Hasibuan, 2007. Manajemen Sumber Daya Manusia. Edisi Revisi penerbit PT. Bumi Askara, Jakarta.

Sugiyono, 2015. Metode Penelitian Kuantitatif Kualitatatif dan R\&N.Edisi ke 22 penerbit CV ALFABETA, Bandung.

Kuzmits, Frank E.,Michael R Carrel.1982. Personnel Manajement of Human Resources. Ohio: Charles E Memil Publishing Company.

Tjutju Yuniarsih, 2009. Manajemen Sumber Daya Manusia.Edisi Kedua. Bandung: Alfabeta. 